\title{
Improving Students' Speaking Ability Using Vlog Media at SMK Negeri 1 Arjasa
}

\author{
Mohammad Ersan ${ }^{1}$, Fabiola D. Kurnia ${ }^{2}$, Eka Fadilah ${ }^{3}$ \\ ${ }^{1,2,3}$ STKIP PGRI Sidoarjo, Indonesia \\ ersanblogger@gmail.com,fabkurnia@gmail.com,mref3k4@gmail.com
}

\begin{abstract}
The primary objective of this study was to ascertain the effectiveness of Vlog and students' perceptions of its implementation in improving students' speaking abilities in the 11th grade of APHPi at SMKN 1 Arjasa. This study used a classroom action research design with subjects in the eleventh grade of APHPi (Agribusiness Processing of Fishery Products). The instruments used were pre- and post-tests, as well as a questionnaire. The results indicated that students implemented Vlog in speaking class twice a cycle, and that the results indicated that students were more engaged in speaking class and that the majority of students improved their ability to speak well. The study's findings indicated that students' achievement increased from the start to the end of the second cycle. The initial condition's average was 65.76, and it increased to 80.30 during the final cycle of the investigation.
\end{abstract}

Keywords

classroom action research; speaking ability; Vlog

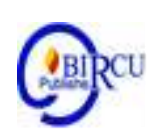

\section{Introduction}

The Covid-19 pandemic is a global catastrophe that has impacted all aspects of life, including education and training (Naciri et al., 2020). Sihombing (2020) state that Covid-19 pandemic caused everyone to behave beyond normal limits as usual. The outbreak of this virus has an impact especially on the economy of a nation and Globally (Ningrum, 2020). The problems posed by the Covid-19 pandemic which have become a global problem have the potential to trigger a new social order or reconstruction (Bara, 2021). Pinatih et al., (2021, state that in the pandemic era, teachers are required to be more creative and innovative in their teaching and learning processes. Speaking is the most difficult skill to teach when learning English during a pandemic, and this is true for all four other language competencies as well. Furthermore, (Pinatih et al., 2021) stated that all fundamental skills are interdependent on one another. The facts, on the other hand, demonstrate that speaking is the most important skill in communication. As a result, language teachers require new approaches to teaching because there is no face-to-face learning process.

A production of using language, according to (Wijaya, 2018), is defined as "speaking." Speaking serves another purpose as well, namely, it is an activity that involves the use of language to communicate between members of a community as a way of demonstrating one's language proficiency. According to Lestari (2019), speaking is an important skill in communicating in language teaching and learning activities, and therefore continuous practice is required in order to improve this skill set. High school students are expected to be able to communicate, but many do not because they lack vocabulary mastery, lack of motivation for 
fear of being wrong, or a lack of practice because they are used to only receiving information and not practicing their communication skills in the classroom. This particular research project focuses on the descriptive text, which is the topic of the speaking class in this particular instance.

In accordance with (Susanti and Amri, 2013), descriptive text is a type of text that is written with the intent of describing a specific person, place or thing. Generally speaking, descriptive text is a type of text that describes the appearance of someone or something. There are many different ways to get a sense of something or someone's physical appearance, smell, sound or voice. Various objects, animals, and people are examples of things that can be described using descriptive text (certain things, our pets or someone we know well). Furthermore, according to the definition provided by Gerot and Wignell (Sahardin et al., 2017), descriptive text is text that is used to describe a specific thing, person, or location. Meanwhile, according to (Ilmiah et al., 2017), descriptive text describes the way things look, smell, taste, taste, or sound, while evaluative text focuses on the content of the text. It can also elicit emotional responses such as happiness, loneliness, or fear in the listener. It is used to create visual representations of people, places, and even units of time such as minutes, hours, and days of the week. It can also be used to describe something other than a person's outward physical appearance. It could provide information about their character traits or personality.

Therefore, we need a learning media that can motivate students to want to talk and improve their speaking skills. Appropriate media will make students more interested and better understand the material. Media can also make teachers more creative and innovative in the teaching and learning process (Parmawati \& Inayah, 2019). And currently, the use of technology is commonplace for the younger generation so a teacher is also required to be able to innovate and one of techniques can be used in teaching speaking by using Vlog (Video Blog) (Fidan, 2018). And more based on opinion (Anggraeni et al., 2020) that the term "vlog" stands for "video blog" referring to blogs but in the form of videos. Vlogs are designed in the form of videos or log in to an event to be uploaded to a platform. In the past, vlogs were called podcasts, because they came from a term that referred to the amalgamation of audio and video blogs. And now the term itself is unified and has own characteristics.

Moreover, (Safitri \& Khoiriyah, 2017) stated video blogging provides a richer experience than sites with text blogging, due to the collaboration of video, sound, images, and text, enhancing the informational content and emotions that are shared with other Internet users. So, Vlog can help students improve their English-speaking ability. Students are better able to tell stories, express ideas, and others. Students can also involve in video blog, as a project assignment. This project assignment is considered effective for them to improve their personal communication skills in foreign languages (Rakhmanina \& Kusumaningrum, 2017). And at the research school, researchers found that many students had difficulty communicating in English due to a lack of fear of making mistakes, mastery of vocabulary, poor grammar and lack of confidence when speaking directly in front of their classmates.

The research conducted by current researchers was in line with third previous studies; the first related study was conducted by Pramita Sari (Sari, 2018) in title "Using Vlog in the Youtube Channel as a Means to Improve Students' Motivation and Confidence to Speak English in Intermediate 1 Level of LB-LIA Jambi". This study aims to improve students' motivation and confidence to speak English through the use of Vlog in the Youtube Channel as well as to find out the element that affect the most to the improvement of the motivation and confidence. The data were obtained through classroom observations, questionnaires and interviews. In terms of findings, this study revealed that the use of Vlog in the Youtube Channel improved students' motivation and confidence. 
The data also suggested that students were most motivated and confident to speak English because they were given enough time to think of what they wanted to talk about and it was done in the place they found familiar. Therefore, teachers are suggested to bring technology into the classrooms more often and adjust it to the situation where students find it convenient to speak up. The similarity the previous study with this research was vlogs can help students to improve their English-speaking skills, because when a student starts doing video blogs in their activities, students will try to add vocabulary and improve pronunciation in their video blogs while the difficulties encountered by the teacher are the lack of facilities for recording student video blogs so that the results of student vlogs are still not optimal. Meanwhile, the difference was the data collection by using interview.

The second related study was conducted by (Anggraeni et al., 2020) in title "Vlog: A Tool for Students' Speaking Practice Enhancement" argued that this research focuses on speaking skill via vlog to see the improvement of students' speaking skill. The method of this research was mixed methods. The research subjects were 13 vlogs made by students on the topic of spot tourism. The 13 vlogs were by assessed using the rubric developed by Dan Rooney (1998). The result found out that using vlog deemed to be improving students' speaking skill especially in the area of vocabulary, fluency, pronunciation and intonation. However, the most common mistakes found are the way they delivered the introduction, how to form conclusions and the last is the grammatical structure. The findings of the research conclude that the application of vlog to improve students' speaking skill found to be successful with a positive perception from students as learning tool. The similarity of this study was learning speaking using vlogs has advantages and disadvantages; the advantage is that students are more enthusiastic in speaking practice because vlogs are the latest media and learning to speak is more interesting and not boring, but on the other hand there are weaknesses in learning with vlogs, namely students must have sophisticated facilities such as smartphones, laptops or computers and must have a good internet connection. Meanwhile the differences were the subject of the study, the location of the study and the method of the study was mixed methods.

The third related study was conducted by (Brilianti, 2015) in title "The Implementation of Video Blog (Vlog) as A Teaching Media in Speaking Skill". In that study explained that the main aim of this study is to investigate the lecturer's strategy in implementing video blog as a media in teaching speaking. Besides, it is also to identify the difficulties of vlog implementation in teaching speaking. To achieve the objectives, the descriptive qualitative approach in the form of a case study was chosen as the method of the research. Observation and interview were collected as the data to the class $2 \mathrm{~A}$, a second-semester student of Computer Engineering Students of Politeknik Harapan Bersama, Tegal, Indonesia. The data from classroom observation were obtained from activity portrait, video recording, students and lecturers' notes, and interview during observation. The data analysis presented by using descriptive explanation, and the data result from lecturers' interview were summarized by using the table and described based on the phenomenon that found during the observation. The finding of data showed that the lecturer applied task- based learning to implement vlog in speaking skill. The lecturers did not only show the vlog to the students in teaching speaking as the media but also asked them to make it by their selves and uploaded it to the YouTube Channel as the new references of English vlog. Lecturers began the learning and teaching process with pre tasks: introduction, review to the previous material; then continued to the main tasks: showing the model/media, giving task, and discussion; and closed by the posttask: evaluation and feedback. Moreover, the difficulties faced by the lecturers in implementing vlog in teaching speaking were a distinct range of students' English scores especially in speaking, the improper gadget that owns by the Students' to make the video blog, and lack of students' creativity in building the video blog content to make it interesting 
to be watched. the descriptive qualitative approach. The similarity of this study is the implementation of vlogs in learning speaking is very helpful for teachers because students are more enthusiastic about learning to increase their vocabulary, grammar and improve how to speak in English. Meanwhile, the difficulty faced by the teacher is determining the assessment criteria because of the difference in student scores in speaking skills; limited devices for recording/making videos that students have and students' creativity in creating vlog content. Besides that, the previous study also has different method with the recent study, namely the descriptive qualitative approach.

According to explanation above, the researcher conducts research at the tenth-grade students of SMK Negeri 1 Arjasa under the title "Improving Students' Speaking Ability Using Vlog Media at SMKN 1 Arjasa”.

\section{Research Methods}

\subsection{Research Design}

This study will be conducted by the aims to describe the improvement of the students' speaking ability and the students' perception on the implementation of vlog for the $11^{\text {th }}$ grade of APHPi at SMKN 1 Arjasa. Thus, the design of this study fits into Classroom Action Research. As Kemmis and Tagart in (Sumarni et al., 2016), action research is research that tries out an idea in practice with the aim of improving it by trying to get a real impact on a particular situation. The action research model is in the form of a spiral from one cycle to the next cycles where each cycle consists of planning (planning), action (action), observation (observation), and reflection (reflection).



Figure 1. Research Design

\subsection{Subject of the Study}

Research location takes place at SMK Negeri 1 Arjasa. It is located on Dusun Ketapang Desa Kolo-Kolo Angkatan Arjasa Sumenep. The study takes place in English class, SMK Negeri 1 Arjasa. The subjects were on Eleventh grade of APHPi (Agribisnis Pengolahan Hasil Perikanan / Agribusiness Processing of Fishery Products). The subjects of the research were the teacher and the students who were involving the study conducted. 


\subsection{Research Procedures}

The action research model is in the form of a spiral from one cycle to the next cycles where each cycle consists of planning, action, observation, and reflection based on Kemmis and Taggart citated by (Defrioka, 2017)

\section{a. Planning}

In the Planning process; the teacher prepares all the tools that were used during the research, such as making learning tools related to vlog, lesson plans, teaching materials.

\section{b. Implementation}

The implementation of learning to speak with English descriptive text material through the application of Vlog media can be described as follows: 1). The teacher opens the lesson and motivates students to take part in the lesson, 2). The teacher conveys the learning objectives, namely so that students are able to understand about the descriptive text and how to describe an object or other orally. 3). The teacher provides students' understanding of the text by sharing a video of the text material. Explanation of the material includes the definition of the text, communicative purpose, generic structure, language features of the text, 4). Students are given the task to answer some questions about the text that has been read, 5). The teacher explains the steps for implementing speaking practice using Vlog as the learning techniques, 6). Students are divided into small groups, containing 2 or 3 people by paying attention to heterogeneity, which means mixing students with low, medium and high competence, 7). The teacher asks students to make vlog with the theme "Tourism Object in Sumenep Regency" for students to work on. After being given the same task for each group in the form of a descriptive topic as vlog, students conduct group discussions to record videos with themes that have been given and when finished, the results of the vlog are uploaded on YouTube, 8). After the video blog uploaded on YouTube is complete, each group presents the results of their respective group videos, 9). Teachers and groups who do not appear give an assessment of the presentations of students who appear, 10). The teacher and students reflect on the results of teaching and learning activities and the teacher explains the material at the next meeting to carry out evaluation activities.

\section{c. Observation}

Observers (collaborators) make observations on student activities and teacher's ability to manage learning by using observation sheets. According to Arikunto in (Isnaini Asa, Muhammad; Santoso, 2019), the observations made were structured observations because on the observation sheet there were criteria that had been observed. The observer gives a check mark $(\sqrt{ })$ on the observation sheet, if the expected student activity in the learning process is displayed and notes other things that are considered important in the notes column provided in the observation sheet. The students' perception about students' speaking skills are assessed based on the rating scale adopted from Heaton which was cited by (Bangun, 2018); rating scale described about students' ability to communicate orally, namely; Strongly Agree (SA), Agree (A), Disagree (DS) and Strongly Disagree (SDS) started from 4-1 respectively based on vlog implemented.

\section{d. Reflection}

From the results of observations and analysis of student activity data based on the criteria of success that are determined based on the English-speaking assessment rubric, reflection will be carried out between teacher and collaborator. From the results of vlog and also observation of activities, reflections will be carried out to determine the progress of the implementation of vlog and students' perception for evaluation and follow-up research. If it 
does not meet the criteria of success, the next cycle of research will be carried out or vice versa.

\subsection{Data Collection Procedures \\ a. Tests}

In order to answer the first research question, the data collection of this research was a test. The test was a collection test speaking ability of descriptive text using vlog of the $11^{\text {th }}$ grade at SMKN 1 Arjasa that uses to determine students' ability. This test consists of two tests which the first was pre-test and the second was post-test.

\section{b. Questionnaire}

In order to gain the students' perception on the implementation of vlog, the questionnaire was used to answer the second research question the students' perceptions on the implementation of Vlog (Video Blog) media in teaching descriptive text the $11^{\text {th }}$ grade at SMKN 1 Arjasa.

\section{c. Criteria of Success}

This study will be classified into success when the criteria of success is met. The Minimum Criteria of Completeness (KKM) is 75 based on the agreement at SMKN 1 Arjasa. Furthermore, it is needed that $75 \%$ was gained by the students in the results of the tests done.

\section{d. Data Analysis}

\section{Tests}

For data analysis in this research, the researcher compares of pre-test and post-test scores, will use descriptive statistics, namely SPSS version 26 . And each test must follow the rubric of speaking score:

Tabel 1. Speaking Rubric

\begin{tabular}{|c|l|c|}
\hline NO. & \multicolumn{1}{|c|}{ ASPECT FOR SPEAKING CRITERIA } & $\begin{array}{c}\text { SCOR } \\
\text { E (1-5) }\end{array}$ \\
\hline 1 & $\begin{array}{l}\text { Grammar (range and accuracy). Student can combine } \\
\text { sentences. Student can use in their oral performance, which } \\
\text { stands for number of grammatical rules and how } \\
\text { accurately/correctly }\end{array}$ & $\begin{array}{l}\text { Vocabulary (range and accuracy). Student can choose the } \\
\text { suitable vocabulary and she/he can use it separately from } \\
\text { sociolinguistic appropriateness of words' selection (i.e., } \\
\text { variant/dialect, style, jargon, etc.). }\end{array}$ \\
\hline 3 & $\begin{array}{l}\text { Pronunciation (individual sounds, stress, rhythm, } \\
\text { intonation, and linking/elision/assimilation). Student can } \\
\text { speak with good pronunciation (comprehensibility in the } \\
\text { first place). }\end{array}$ & $\begin{array}{l}\text { Fluency (speed of talking, hesitation while speaking, } \\
\text { hesitation before speaking). students' ability to speak } \\
\text { naturally without worrying too much about being } \\
\text { completely accurate. }\end{array}$ \\
\hline 5 & $\begin{array}{l}\text { Conversational skill (topic development, initiative, and } \\
\text { conversation maintenance). Student can speak as the topic } \\
\text { or coherence with the topic discussed. }\end{array}$ & \\
\hline
\end{tabular}




\begin{tabular}{|c|l|l|}
\hline 6 & $\begin{array}{l}\text { Sociolinguistic skill (distinguishing register and style, use } \\
\text { of cultural references). }\end{array}$ & $\begin{array}{l}\text { Non-verbal (eye-contact and body language). Student can } \\
\text { express the speaking involves not only producing the } \\
\text { words, but also the message expressed with the help of } \\
\text { body (posture, gestures, facial expressions, eye contact) }\end{array}$ \\
\hline 8 & $\begin{array}{l}\text { Content (relevance of arguments and ideas). This criterion } \\
\text { refers to logic and consistent arrangement of arguments, } \\
\text { ideas, comments, etc. to the speakers' point, leading to } \\
\text { better and easier understanding }\end{array}$ & \\
\hline
\end{tabular}

Adapted from (Venera, 2017)

\section{Questionnaire}

These questionnaires are used to gain students' information about their perception in learning English by using Vlog. The questionnaire is constructed from theory of perception. The questionnaire will be in the form of Likert Scale. There are four scales ranging from Strongly Agree (SA), Agree (A), Disagree (DS) and Strongly Disagree (SDS) started from 41 respectively. The result of this research can be used as a recommendation whether vlog is effective to be applied. The evaluation criteria to measure students' perception is in the form of percentage of students' answer on the questionnaire.

Table 2. Likert Scale

\begin{tabular}{|c|l|c|}
\hline No & \multicolumn{1}{|c|}{ Categories } & Score \\
\hline 1 & Strongly Agree (SA) & 4 \\
\hline 2 & Agree (A) & 3 \\
\hline 3 & Disagree (D) & 2 \\
\hline 4 & Strongly Disagree (SD) & 1 \\
\hline
\end{tabular}

Adapted from (Basri et al., 2021)

Table 3. Questionnaire's Questions

\begin{tabular}{|c|c|}
\hline No. & Questionnaire's Question \\
\hline 1 & Vlog offers me more opportunities to interact with my teacher and peers \\
\hline 2 & Vlog can bulit my confidence \\
\hline 3 & $\begin{array}{l}\text { Vlog gives me a chance to share my speaking ability with my teacher and } \\
\text { peers }\end{array}$ \\
\hline 4 & $\begin{array}{l}\text { vlog allows me to get immediate feedback from my teacher and peers by } \\
\text { comment and subscribe }\end{array}$ \\
\hline 5 & $\begin{array}{l}\text { vlog supports e-learning through speaking Video and building confidence } \\
\text { in groups. }\end{array}$ \\
\hline 6 & vlog can motivate me in learning speaking class \\
\hline 7 & vlog requires long time to master its implement \\
\hline
\end{tabular}




\begin{tabular}{|c|l|}
8 & $\begin{array}{l}\text { I need to learn something trouble shooting technology tasks to help } \\
\text { myself when implementing vlog properties }\end{array}$ \\
\hline 9 & $\begin{array}{l}\text { I dislike using vlog as my speaking media because I must have good } \\
\text { devices and washing my time }\end{array}$ \\
\hline 10 & $\begin{array}{l}\text { I get frustrated by practicing speaking in vlog because of the slow-speed } \\
\text { internet }\end{array}$ \\
\hline
\end{tabular}

SA: Strongly Agree, A: Agree, D: Disagree, SD: Strongly Disagree

Adapted from (Widodo, J. P. \& Slamet, J., 2020)

\section{Discussion}

It is accurate to say that using video blogs to teach speaking can improve students' speaking skills in terms of acceptable pronunciation, correct grammar, and appropriate vocabulary. This is demonstrated by the significant difference between the values obtained from the pre- and post-test. However, there are some difficulties encountered when recording the vlog activity due to the geographical location of the Arjasa archipelago, which is windy, necessitating the use of a device with good stabilizers to capture the activity. Then, in this section, the researcher discusses the findings of his research, which included the results of students' speaking ability after the implementation of video blogs and questionnaires distributed to 33 students in the 11th grade of APHPi about using video blogs as a media to improve students' speaking skills. The results of the pretest and posttest scores as well as the response questionnaire to students' perceptions are described as follows:

\subsection{The Students'score of Implementation Vlog in Speaking Class}

Tabel 4. Students' Speaking Score

\begin{tabular}{|c|c|c|c|c|c|}
\hline \multicolumn{6}{|c|}{ Descriptive Statistics } \\
\hline & $\mathrm{N}$ & $\begin{array}{l}\text { Minim } \\
\text { um }\end{array}$ & $\begin{array}{l}\text { Maxim } \\
\text { um }\end{array}$ & Mean & $\begin{array}{c}\text { Std. } \\
\text { Deviation }\end{array}$ \\
\hline Pretest & 33 & 40 & 80 & 65.76 & 12.755 \\
\hline Posttest & 33 & 70 & 90 & 80.30 & 5.294 \\
\hline $\begin{array}{l}\text { Valid N } \\
\text { (listwise) }\end{array}$ & 33 & & & & \\
\hline
\end{tabular}

Based on the results of the descriptive statistics in students' speaking score, it can be described as follows, the number of respondents in $11^{\text {st }}$ grade of APHPi was 33 students with a minimum pretest score of 40 and a maximum score of 80 , while the minimum posttest score was 70 and the maximum value was 90 . Meanwhile, the standard deviation value of the pretest was 12,755 and the posttest was 5,294.

Tabel 5. Tests of Normality

\begin{tabular}{|c|c|c|c|c|c|c|c|}
\hline & \multirow[t]{2}{*}{ Kelas } & \multicolumn{3}{|c|}{ orov-Sm } & \multicolumn{3}{|c|}{ Shapiro-Wilk } \\
\hline & & $\begin{array}{c}\text { Statisti } \\
\text { c }\end{array}$ & df & Sig. & $\begin{array}{c}\text { Statisti } \\
\text { c }\end{array}$ & df & Sig. \\
\hline Hasil & Pretest & .176 & 33 & .011 & .876 & 33 & .001 \\
\hline Belajar & $\begin{array}{l}\text { Post- } \\
\text { test }\end{array}$ & .235 & 33 & .000 & .905 & 33 & .007 \\
\hline
\end{tabular}

a. Lilliefors Significance Correction 
According to the data in the preceding table, the significance value (p-value) for the normality test using the Shapiro method for the pretest variable is $0.001(10 \%)$ which means $\mathrm{p}>\alpha: 10 \%>5 \%$ and the posttest variable is $0.007(70 \%)$ which significance $<0.005(5 \%)$. The conclusion is that $\mathrm{Ha}$ is accepted and $\mathrm{H}_{0}$ is rejected, which means that the data comes from a normally distributed population. In other words, teaching speaking skills through the use of vlog media has an impact on students' ability to communicate, or the vlog method is an effective method for teaching speaking skills in speaking class.

\subsection{Students' Perception of Implementation Vlog in Speaking}

\begin{tabular}{c|c}
\multicolumn{2}{c}{ Tabel 6. Reliability Statistics } \\
$\begin{array}{c}\text { Cronbach's } \\
\text { Alpha }\end{array}$ & N of Items \\
\hline .187 & 10 \\
\hline
\end{tabular}

Based on table 6 above, it is known that the Cronbach's Alpha value for the variable student perception of the use of Vlog media is 0.187 , which means more than 0.50 . It can be concluded that the instrument is reliable to be used as a research instrument.

\section{Conclusion}

Based on the findings of the research and discussion, it can be concluded that the students implemented Vlog in speaking class in two meetings each cycle, and that the results of the implementation of using Vlog showed that the students were more enthusiastic in speaking class and that the majority of the students were able to improve their ability to speak well. The results of the study showed that students' achievement increased from the beginning of the study to the end of the second cycle. The average of the initial condition was 65.76, and it increased to 80.30 in the last cycle of the treatment done.

In light of the results of this research, there are a number of things that can be suggested as potential future improvements: (1) The learning strategy employed by the teacher must be able to pique the interest and participation of students in the learning process, allowing them to become more active and communicate more fluently. (2) The characteristics of students and schools must be taken into consideration when using new technology as a learning medium. Because it will allow teachers and students to choose and use appropriate learning strategies, the selection of learning media used in learning at SMK Negeri 1 Arjasa is critical because it will foster interaction between teaching and learning materials. (3) Teachers should use this approach as an alternative action in overcoming the difficulties of learning English in this extremely difficult situation (Covid-19), particularly in order to increase the number of learning activities conducted by students. Then, teachers should devise assessment techniques that are comprehensive, meaningful, and authentic, and that can be used to determine whether or not students have achieved mastery of the material., (4) Other researchers should be able to build on this research in order to make it more generalizable in proportion to the findings. Similar research should be carried out in other English-speaking materials, as well, it is recommended. This is based on the assumption that students' ability to communicate verbally is becoming increasingly proficient. Because, at the time of the research, students were extremely enthusiastic and happy to participate in learning activities that they taught were not boring to learn and motivated the students in communication using English, despite the fact that English was a foreign language in Indonesia at the time of the research. 


\section{References}

Anggraeni, A., Rachmijati, C., \& Apriliyanti, D. L. (2020). Vlog: A Tool for Students' Speaking Practice Enhancement. Research and Innovation in Language Learning, 3(1), 23-31. https://doi.org/10.33603/rill.v3i1.2775

Bangun, B. K. (2018). Improving Students' Speaking Skill by Using Show and Tell Method: A Classroom Action Research. International Journal of Language Teaching and Education, 2(1), 41-48. https://doi.org/10.22437/ijolte.v2i1.4517

Bara, A., et.al. (2021). The Effectiveness of Advertising Marketing in Print Media during the Covid 19 Pandemic in the Mandailing Natal Region. Budapest International Research and Critics Institute-Journal (BIRCI-Journal) Vol 4 (1): 879-886.

Basri, M., Husain, B., \& Modayama, W. (2021). University Students' Perceptions in Implementing Asynchronous Learning during Covid-19 Era. Metathesis: Journal of English Language, Literature, and Teaching, 4(3), 263. https://doi.org/10.31002/metathesis.v4i3.2734

Brilianti, D. F. Y. F. (2015). The Implementation of Video Blog (Vlog) As A Teaching Media in Speaking Skill. 4(1), 339-351.

Defrioka, A. (2017). The Use of Information Gap Activities in Teaching Speaking (Classroom Action Research at SMK). Lingua Didaktika: Jurnal Bahasa Dan Pembelajaran Bahasa, 10(2), 116. https://doi.org/10.24036/ld.v10i2.6418

Fidan, M. (2018). The Usage of Video Blog (vlog) in the "School Experience" Course: The Opinions of the Pre-service Teachers. Journal of Education and Future, 13, 161-177.

Ilmiah, Supardin, \& Latief, H. (2017). Improving The Students' Ability to Write Descriptive Texts Through Four Square Writing Method View metadata, citation and similar papers at core.ac.uk. View Metadata, Citation and Similar Papers at Core.Ac.Uk., 6(1), 274282. https://core.ac.uk/download/pdf/233602812.pdf

Isnaini Asa, Muhammad; Santoso, A. B. (2019). International Journal of Education Humanities and Social Science. International Journal of Education Humanities and Social Science, 2(03), 47-56.

Lestari, N. (2019). Improving the Speaking Skill by Vlog (video blog) as Learning Media: The EFL Students Perspective. International Journal of Academic Research in Business and Social Sciences, 9(1), 915-925. https://doi.org/10.6007/ijarbss/v9-i1/5490

Naciri, A., Baba, M. A., Achbani, A., \& Kharbach, A. (2020). Mobile Learning in Higher Education: Unavoidable Alternative during COVID-19. Aquademia, 4(1), ep20016. https://doi.org/10.29333/aquademia/8227

Ningrum, P.A., Hukom, A., and Adiwijaya, S. (2020). The Potential of Poverty in the City of Palangka Raya: Study SMIs Affected Pandemic Covid 19. Budapest International Research and Critics Institute-Journal (BIRCI-Journal) Vol 3 (3): 1626-1634.

Parmawati, A., \& Inayah, R. (2019). Improving Students' Speaking Skill Through English Movie in Scope of Speaking for General Communication. ELTIN Journa, 7(III), 3.

Pinatih, I. G. A. D. P., Nitiasih, P. K., Budiartaluh G. R., \& Adnyayanti, N. L. P. E. (2021). Boosting Students' Speaking Skill in the Pandemic Era Using Problem Based Learning Video. PROJECT (Professional Journal of English Education), 4(5), 893-899. https://www.journal.ikipsiliwangi.ac.id/index.php/project/article/view/7281

Rakhmanina, L., \& Kusumaningrum, D. (2017). the Effectiveness of Video Blogging in Teaching Speaking Viewed from Students' Learning Motivation. Proceedings of $\begin{array}{lllll}\text { ISELT FBS Universitas Negeri Padang, } & 017 .\end{array}$ http://ejournal.unp.ac.id/index.php/selt/article/view/7980

Safitri, N., \& Khoiriyah, I. (2017). Students' Perceptions on the Use of English Vlog (Video Blog) to Enhance Speaking Skill 1 Nailis Sa'adah Safitri, 2 Ianatul Khoiriyah. The 5th 
AASIC,

247.http://103.216.87.80/index.php/selt/article/view/7980/6083\%0Ahttp://ejournal.usd.ac.id/index.php/LLT

Sahardin, R., Hanum, C. S., \& Gani, S. A. (2017). Using Think-Pair-Share for writing descriptive texts. Studies in English Language and Education, 4(1), 54. https://doi.org/10.24815/siele.v4i1.7004

Sari, P. (2018). Using Vlog in the Youtube Channel as a Means to Improve Students' Motivation and Confidence to Speak English in Intermediate 1 Level of LB-LIA Jambi. International Journal of Language Teaching and Education, 1(1), 38-44. https://doi.org/10.22437/ijolte.v1i1.4596

Sihombing, E.H., and Nasib. (2020). The Decision of Choosing Course in the Era of Covid 19 through the Telemarketing Program, Personal Selling and College Image. Budapest International Research and Critics Institute-Journal (BIRCI-Journal) Vol 3 (4): 28432850 .

Sumarni, W., Wardani, S., Sudarmin, S., \& Gupitasari, D. N. (2016). Project based learning (PBL) to improve psychomotoric skills: A classroom action research. Jurnal Pendidikan IPA Indonesia, 5(2), 157-163. https://doi.org/10.15294/jpii.v5i2.4402

Susanti, E., \& Amri, Z. (2013). Speaking Board Game to Teach Speaking of Descriptive Text. Journal of English Language Teaching, 1(2), 456-463.

Venera, U. (2017). The Design and Use of Speaking Assesment Rubrics. Journal of Education and Practice, 8(32), 135-141.

Widodo, J. Priyono;Slamet, J. (2020). Students' Perception Towards Google Classroom as ELearning Tool. ISSN 2622-7959 Edisi No. 48 Oktober 2020, 9 (May), 6.

Wijaya, T. W. (2018). The Effectiveness of Songs for Teaching Speaking. Journal of Foreign Languange Teaching and Learning, 3(2). https://doi.org/10.18196/ftl.3231 